\title{
Prodrugs of 9-Benzyl-8-hydroxy-2-(2-hydroxyethylthio)adenine: Potent Interferon Inducing Agents in Monkeys
}

\author{
Ayumu Kurimoto, Masanori Tobe, Haruhisa Ogita, Tetsuhiro Ogino, Haruo Takaku, Shinji IchiI, \\ Hajime KaWAKAmI, and Yoshiaki IsOBE* \\ Research Division, Discovery Research Laboratories II, Sumitomo Pharmaceuticals Co. Ltd.; 3-1-98 Kasugade Naka, \\ Konohana-ku, Osaka 554-0022, Japan. Received November 13, 2003; accepted January 20, 2004
}

In order to improve the oral bioavailability of 9-benzyl-8-hydroxy-2-(2-hydroxyethylthio)adenine (SM295072), a potent interferon (IFN) inducing agent, we synthesized prodrugs of it by utilizing the hydroxy groups at the $C(2)$-side chain and/or the $C(8)$-position. The carbonate prodrug at the $C(8)$-position was more effective than that at the $\mathrm{C}(2)$-side chain for oral absorption in rats. Among the compounds prepared, compound 6 demonstrated the most preferable prodrug properties, and the maximum plasma concentration of 6 was approximately 4-fold higher than that of SM-295072. Furthermore, compound 6 was dose-dependently absorbed in monkeys by oral administration, and exhibited a potent IFN-inducting activity that correlated well with its plasma drug concentration.

Key words prodrug; 8-hydroxyadenine; interferon inducing agent; antiviral

The clinical need for therapeutic agents which restore and enhance the host's natural immuno response in immunocompromised patients such as occurs in viral infections, cancer, autoimmune diseases, and acquired immuno deficiency syndrome (AIDS) has led to the search for novel immunostimulants. ${ }^{1)}$

Interferons (IFNs) are one of the naturally occurring cytokines that mediate a wide range of biological effects, including antiviral, antiproliferative, and immunomodulatory activities. ${ }^{2-4)}$ Currently, there are two different approaches to the use of IFN in clinical therapies. Enhancing the immuno response by the administration of exogenous IFN is one strategy, and this has been successfully used as a component in the therapy for treatment of chronic hepatitis $\mathrm{C}$ virus (HCV) hepatitis and hairy-cell leukemia. ${ }^{5,6}$ IFN therapy is, however, associated with significant problems, for example patient compliance and a loss of therapeutic efficacy as a result of the formation of neutralizing antibodies against exogenous IFN. ${ }^{7,8)}$ Induction in the organism of endogenous IFN synthesis with exogenous IFN inducers is an alternative approach. Orally bioavailable IFN inducing agents offer the possible advantages of convenience and avoidance of immunogenicity.

Recently, we have preliminarily reported the discovery of a series of 8-hydroxyadenines which are members of a new group of low molecular weight compounds. They have been shown to have IFN-inducing activities both in vitro and in vivo in mice. ${ }^{9)}$ In the course of our structure and activity relationship studies, we selected 9-benzyl-8-hydroxy-2-(2-hydroxyethylthio)adenine (SM-295072) as a development candidate for treatment of the above viral diseases from a view point of both activities and toxicities (Fig. 1). ${ }^{10)}$ SM-295072 induced IFN over at a concentration of $0.1 \mu \mathrm{M}$ in mice splenocyte in vitro, and IFN induction was observed in

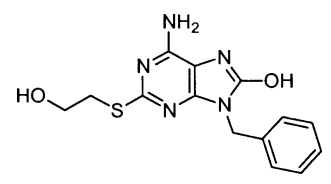

plasma over a dose of $0.1 \mathrm{mg} / \mathrm{kg}$ by oral administration to mice. However, SM-295072 did not induce IFN in monkeys by oral administration even at a dose of $100 \mathrm{mg} / \mathrm{kg}$, given as a suspension in $0.5 \%$ sodium carboxymethyl cellurose (CMC-Na) solution. The maximum concentration $\left(C_{\max }\right)$ of SM-295072 was reached only $16.7 \mathrm{ng} / \mathrm{ml}(c a .0 .05 \mu \mathrm{M})$. Moreover, SM-295072 exhibited low solubilities not only in water, but also in various organic solvents, such as ethyl acetate, hexane, ethanol. Therefore, we considered that the low $C_{\max }$ value of SM-295072 reflected its low solubility.

In order to improve the $C_{\max }$ value of SM-295072, we initiated a program of prodrug synthesis by utilizing the hydroxy groups of SM-295072. In the present study, we synthesized and evaluated various prodrugs of SM-295072 to investigate their influence on the pharmacokinetic properties and biological activities.

Chemistry The synthetic routes to the compounds (18) are shown in Chart 1. SM-295072 was treated with 3 equivalents of chloroformate in pyridine to afford the dicarbonates $(\mathbf{1}, \mathbf{2})$ in good yield. Treatment of SM-295072 with 1 equivalent of butyl chloroformate in pyridine gave the $C(2)$ side chain monocarbonate 3 and $C(8)$-monocarbonate 4 in

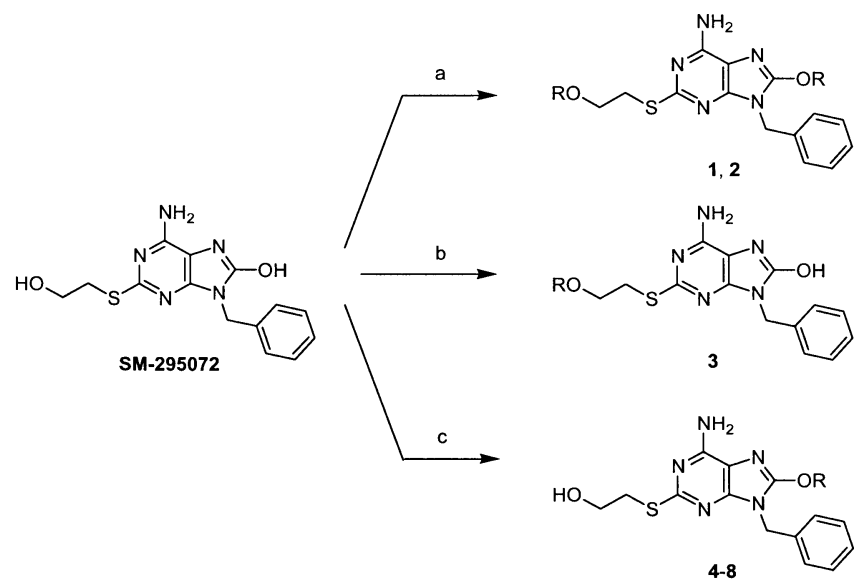

Reagents and conditions: (a); $\mathrm{ClCO}_{2} \mathrm{R}$ (3 equiv.)/ Pyridine, r.t., (b) $\mathrm{ClCO}_{2} \mathrm{R}$ (1 equiv.)/ Pyridine, r.t., (c); $\mathrm{ClCO}_{2} \mathrm{R}$ (1.5 equiv.), $\mathrm{Et}_{3} \mathrm{~N} / \mathrm{CHCl}_{3}$, r.t. 
Table 1. Pharmacokinetic Properties of SM-295072 and Its Prodrugs in Rats

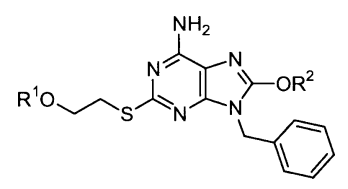

\begin{tabular}{|c|c|c|c|c|c|}
\hline & \multicolumn{2}{|c|}{ Compound } & \multirow{2}{*}{$C_{\max }^{a)}(\mu \mathrm{g} / \mathrm{ml})$} & \multirow{2}{*}{$T_{\max }^{a)}(\mathrm{h})$} & \multirow{2}{*}{$A U C^{a)}(\mu \mathrm{g} / \mathrm{ml} \cdot \min )$} \\
\hline & $\mathrm{R}^{1}$ & $\mathrm{R}^{2}$ & & & \\
\hline SM-295072 & $\mathrm{H}$ & $\mathrm{H}$ & $0.07^{b)}$ & $1^{b)}$ & $67^{b)}$ \\
\hline 1 & $\mathrm{CO}_{2} \mathrm{Et}$ & $\mathrm{CO}_{2} \mathrm{Et}$ & $0.13^{b)}$ & $1^{b)}$ & $91^{b)}$ \\
\hline 2 & $\mathrm{CO}_{2} \mathrm{Bu}$ & $\mathrm{CO}_{2} \mathrm{Bu}$ & $0.13^{b)}$ & $4^{b)}$ & $91^{b)}$ \\
\hline 3 & $\mathrm{CO}_{2} \mathrm{Bu}$ & $\mathrm{H}$ & 0.07 & 1 & 61 \\
\hline 4 & $\mathrm{H}$ & $\mathrm{CO}_{2} \mathrm{Bu}$ & 0.12 & 1 & 104 \\
\hline 5 & $\mathrm{H}$ & $\mathrm{CO}_{2} \mathrm{Me}$ & 0.09 & 1 & 58 \\
\hline 6 & $\mathrm{H}$ & $\mathrm{CO}_{2} \mathrm{Et}$ & 0.28 & 1 & 158 \\
\hline 7 & $\mathrm{H}$ & $\mathrm{CO}_{2} \mathrm{Pr}^{\mathrm{i}}$ & 0.14 & 1 & 49 \\
\hline 8 & $\mathrm{H}$ & $\mathrm{CO}_{2} \mathrm{Bu}^{\mathrm{i}}$ & 0.04 & 1 & 25 \\
\hline
\end{tabular}

a) Compounds were examined for pharmacokinetics when orally adminstered to rats at a dose of $30 \mathrm{mg} / \mathrm{kg}$ with $0.5 \% \mathrm{CMC}-\mathrm{Na}$. The results are expressed as the mean of two rats. Each pharmacokinetic parameter was determined from detected SM-295072. b) The results are expressed as the mean of three rats.

a ratio of approximately $1: 2$. These compounds were separated by column chromatography. Interestingly, when SM295072 was reacted with chloroformate in the presence of triethylamine instead of pyridine, the monocarbonates $4-\mathbf{8}$ were selectively formed.

\section{Results and Discussion}

In order to evaluate oral absorption of compounds $(\mathbf{1}-\mathbf{8})$, the compounds were suspended in $0.5 \% \mathrm{CMC}-\mathrm{Na}$ solution and were orally administered to rats. The plasma concentrations of each compounds (1-8) and SM-295072 were measured by a HPLC method and the detection limits were $0.01 \mu \mathrm{g} / \mathrm{ml}$. Therefore, the compounds were administered at a dose of $30 \mathrm{mg} / \mathrm{kg}$ in order to detect the compounds in the blood samples. After each compound (1-8) was orally administered to rats, only SM-295072 was confirmed in any blood collection points (data not shown). Therefore, we considered that each compound was rapidly converted into the parent compound (SM-295072), and thus functioned as a prodrug. The $C_{\max }, T_{\max }$ and area under the curve $(A U C)$ values by the administration of the compounds $(\mathbf{1}-\mathbf{8})$ were summarized in Table 1.

As expected, the dicarbonates $(\mathbf{1}, \mathbf{2})$ displayed good prodrug properties. The $C_{\max }$ values of these compounds were approximately 2-fold higher than that of SM-295072, and the alkyl chain length did not seem to have an effect on the absorption. In order to explore the influence of carbonate at the $C(2)$-side chain and the $C(8)$-position, compounds 3 and $\mathbf{4}$ were synthesized and evaluated. The $C_{\max }$ and $A U C$ values of 3 were comparable to those of SM-295072, while compound 4 showed more preferable $C_{\max }$ and $A U C$ values than SM295072. These results suggested that the carbonate at the $C(8)$-position was more effective than that at the $C(2)$-side chain. Next, in an attempt to evaluate the effect of alkyl moieties of the alkylcarbonate at the $C(8)$-position, compounds 5-8 were prepared and the $C_{\max }$ and $A U C$ values determined. Among the prepared compounds, compound 6, containing an ethyl carbonate, showed the best properties. The $C_{\max }$ and $A U C$ values of $\mathbf{6}$ were much higher than those of the parent compound, SM-295072. Further elongation of alkyl chain resulted in decreasing each pharmacokinetic parameter value and it seems that the suitable alkyl chain length exists.

Furthermore, the solubility and the Caco-2 permeability of SM-295072 and 6 were measured. SM-295072 and 6 possessed almost the same solubilities $(<10 \mu \mathrm{g} / \mathrm{ml})$, but the apparent permeabilities $\left(P_{\text {app }}\right)$ of these compounds were 23 and $111 \mathrm{~nm} / \mathrm{s}$, respectively. Compound 6 exhibited a 4.8-fold increase in $P_{\text {app }}$ compare to that of the parent compound, SM295072, and these results suggested that $\mathbf{6}$ showed improved absorption due to its increase in $P_{\text {app }}$.

Finally, compound $\mathbf{6}$ was evaluated in monkeys. Imiquimod is known to have an antiviral property mediated by the induction of IFN. Imiquimod induces IFN at a dose of $10 \mathrm{mg} / \mathrm{kg}$ in monkey ${ }^{11)}$ and the clinical trials of Imiquimod for treatment of $\mathrm{HCV}$ infections, were conducted at a dosage ranging between 100 and $200 \mathrm{mg}$ per day $(2-4 \mathrm{mg} / \mathrm{kg})$. Thus, Compound $\mathbf{6}$ was orally administered to monkeys at doses of 10 and $100 \mathrm{mg} / \mathrm{kg}$, given as a suspension in $0.5 \%$ CMC-Na solution. Each blood sample was collected, and the plasma concentration of SM-295072 was measured by a HPLC method. The amounts of IFN in the plasma were measured by bioassay system using L929 cells infected with vesicular stomatitis virus and these results are shown in Figs. 2 and 3.

The $C_{\max }$ value of 6 was approximately 2 -fold higher than that of SM-295072 at a dose of $10 \mathrm{mg} / \mathrm{kg}$, and was $30 \mathrm{ng} / \mathrm{ml}$. At this dose $248 \mathrm{IU} / \mathrm{ml}$ of IFN-induction was observed. The $C_{\max }$ value of 6 was dose-dependently increased and the IFNinducing activity correlated well with the drug concentration. In contrast, SM-295072 did not show such a property, i.e.; the $C_{\max }$ value at a dose of $100 \mathrm{mg} / \mathrm{kg}$ is $16.7 \mathrm{ng} / \mathrm{ml}$, which is almost the same value with that at a dose of $10 \mathrm{mg} / \mathrm{kg}$. From these results, the prodrug $\mathbf{6}$ provides considerable advantages compared to SM-295072.

\section{Conclusion}

In order to improve the low $C_{\max }$ value of SM-295072, we synthesized the prodrugs of it by utilizing the hydroxy groups at the $C(2)$-side chain and/or the $C(8)$-position and evaluated their oral absorption in rats. The carbonate prodrug 


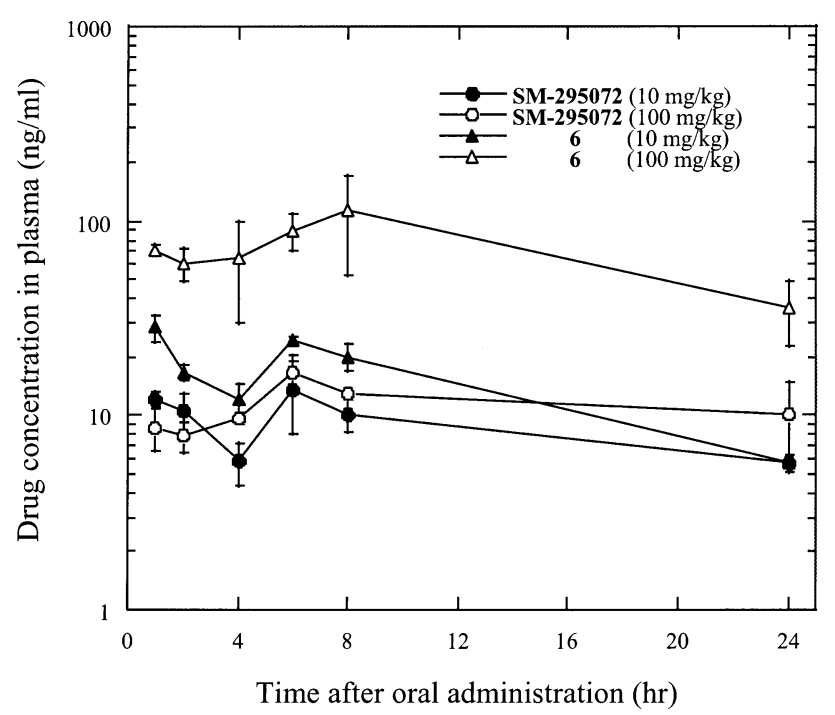

Fig. 2. Plasma Concentration of SM-295072 after Oral Administration of SM-295072 and 6 in Monkey

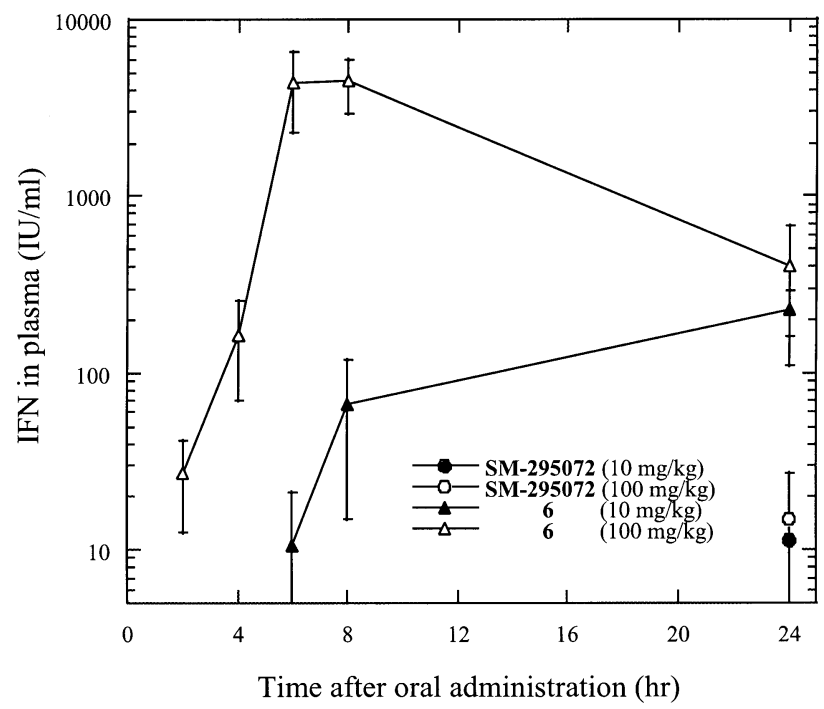

Fig. 3. Plasma IFN Level after Oral Administration of SM-295072 and 6 in Monkey

at the $C(8)$-position was effective than that at the $C(2)$-side chain for oral absorption in rats. Among the test compounds, compound 6 demonstrated the most preferable pharmacokinetic properties, and in particular the $C_{\max }$ value of $\mathbf{6}$ was approximately 4-fold higher compared with that of SM295072. Compound 6 exhibited dose-dependent IFN inducing activity into plasma in monkeys by oral administration.

From the above results, we consider that compound $\mathbf{6}$ is a very attractive prodrug of SM-295072. We are continuing to evaluate additional pharmacokinetic studies of $\mathbf{6}$ for preclinical studies.

\section{Experimental}

Chemistry Melting points were measured on a Thomas Hoover capillary melting point apparatus and were uncorrected. Nuclear magnetic resonance (NMR) spectra were recorded at ambient temperature on a JEOL JNM LA-300 or a Bruker AVANCE 400 FT NMR spectrometer. Chemical shifts were expressed in $\delta$ values (ppm) relative to tetramethylsilane as an internal standard, and signals are expressed s (singlet), d (doublet), $\mathrm{t}$ (triplet), q (quartet), m (multiplet), or br (broad). Mass spectra (MS) were measured on a JEOL JMS-AX505W or JEOL JMS-SX102A mass spectrometer. Elemental analyses were performed by Sumika Chemical Analysis Service, Osaka, Japan. Commercial reagents and solvents were of reagent grade and used without further purification. Thin-layer chromatography (TLC) was performed on Merck Kieselgel $60 \mathrm{~F}_{254}$ precoated plates and components were visualized using UV light. Chromatography was conducted using Merk Kieselgel $60 \mathrm{~F}_{254}$ or Cica-Reagent Silica Gel 60.

9-Benzyl-8-ethoxycarbonyloxy-2-[2-(ethoxycarbonyloxy)ethylthio]adenine (1) To a solution of SM-295072 $(100 \mathrm{mg}, 0.315 \mathrm{mmol})$ in pyridine $(5 \mathrm{ml})$ was added dropwise ethyl chloroformate $(103 \mathrm{mg}, 0.945 \mathrm{mmol})$ and the mixture was stirred at room temperature for $10 \mathrm{~h}$ and then evaporated in vacuo. The residue was partitioned with water $(50 \mathrm{ml})$ and $\mathrm{CHCl}_{3}(100 \mathrm{ml})$ and the organic layer was separated, dried over $\mathrm{Na}_{2} \mathrm{SO}_{4}$ and then evaporated in vacuo. The residue was purified by silica gel column chromatography (hexane-ethyl acetate $3: 1)$ to give $\mathbf{1}(110 \mathrm{mg}, 76 \%)$ as a colorless solid. $\mathrm{mp}$ $147-149^{\circ} \mathrm{C}$; ${ }^{1} \mathrm{H}-\mathrm{NMR}$ (DMSO- $\left.d_{6}\right) \delta 7.31(5 \mathrm{H}, \mathrm{m}), 7.16(2 \mathrm{H}, \mathrm{brs}), 4.91$ $(2 \mathrm{H}, \mathrm{s}), 4.38(2 \mathrm{H}, \mathrm{q}, J=7.2 \mathrm{~Hz}), 4.26(2 \mathrm{H}, \mathrm{t}, J=6.6 \mathrm{~Hz}), 4.11(2 \mathrm{H}, \mathrm{q}, J=7.2$ $\mathrm{Hz}), 3.31(2 \mathrm{H}, \mathrm{t}, J=6.6 \mathrm{~Hz}), 1.32(3 \mathrm{H}, \mathrm{t}, J=7.2 \mathrm{~Hz}), 1.20(3 \mathrm{H}, \mathrm{t}, J=7.2 \mathrm{~Hz})$; MS (FAB) $m / z 462\left(\mathrm{MH}^{+}\right)$; HR-MS Calcd for $\mathrm{C}_{20} \mathrm{H}_{24} \mathrm{~N}_{5} \mathrm{O}_{6} \mathrm{~S} 462.1447$, found 462.1443. Anal. Calcd for $\mathrm{C}_{20} \mathrm{H}_{23} \mathrm{~N}_{5} \mathrm{O}_{6} \mathrm{~S}: \mathrm{C}, 52.05 ; \mathrm{H}, 5.02 ; \mathrm{N}, 15.18$. Found: C, 51.83; H, 5.06; N, 15.11 .

9-Benzyl-8-butoxycarbonyloxy-2-[2-(butoxycarbonyloxy)ethylthio]adenine (2) Compound 2 was prepared from butyl chloroformate and SM295072 in a manner similar to that described for compound 1. Colorless solid $(82 \%), \mathrm{mp} 119-121^{\circ} \mathrm{C} ;{ }^{1} \mathrm{H}-\mathrm{NMR}$ (DMSO- $\left.d_{6}\right) \delta 7.30(5 \mathrm{H}, \mathrm{m}), 7.16$ $(2 \mathrm{H}, \mathrm{brs}), 4.91(2 \mathrm{H}, \mathrm{s}), 4.34(2 \mathrm{H}, \mathrm{q}, J=6.3 \mathrm{~Hz}), 4.26(2 \mathrm{H}, \mathrm{t}, J=6.3 \mathrm{~Hz}), 4.06$ $(2 \mathrm{H}, \mathrm{t}, J=6.6 \mathrm{~Hz}), 3.30(2 \mathrm{H}, \mathrm{t}, J=6.6 \mathrm{~Hz}), 1.70-1.23(8 \mathrm{H}, \mathrm{m}), 0.88(6 \mathrm{H}$, m); MS (FAB) $m / z 518\left(\mathrm{MH}^{+}\right)$; HR-MS Calcd for $\mathrm{C}_{24} \mathrm{H}_{32} \mathrm{~N}_{5} \mathrm{O}_{6} \mathrm{~S} 518.2073$, found 518.2078. Anal. Calcd for $\mathrm{C}_{24} \mathrm{H}_{31} \mathrm{~N}_{5} \mathrm{O}_{6} \mathrm{~S}: \mathrm{C}, 55.69 ; \mathrm{H}, 6.04 ; \mathrm{N}, 13.53$. Found: C, 55.47; H, 6.00; N, 13.36 .

9-Benzyl-8-hydroxy-2-[2-(butoxycarbonyloxy)ethylthio]adenine (3) To a solution of SM-295072 $(100 \mathrm{mg}, 0.315 \mathrm{mmol})$ in pyridine $(5 \mathrm{ml})$ was added dropwise butyl chloroformate $(43 \mathrm{mg}, 0.315 \mathrm{mmol})$ and the mixture was stirred at room temperature for $2 \mathrm{~h}$, then evaporated in vacuo. The residue was partitioned with water $(50 \mathrm{ml})$ and $\mathrm{CHCl}_{3}(100 \mathrm{ml})$ and the organic layer was separated, dried over $\mathrm{Na}_{2} \mathrm{SO}_{4}$ and then evaporated in vacuo. The residue was purified by silica gel column chromatography $(1 \% \mathrm{MeOH}-$ $\left.\mathrm{CHCl}_{3}\right)$ to give $\mathbf{3}(21 \mathrm{mg}, 13 \%)$ as a colorless solid and $\mathbf{4}(35 \mathrm{mg}, 27 \%)$ as a colorless solid. mp $163-166{ }^{\circ} \mathrm{C} ;{ }^{1} \mathrm{H}-\mathrm{NMR}$ (DMSO- $\left.d_{6}\right) \delta 10.31(1 \mathrm{H}, \mathrm{brs})$, $7.28(5 \mathrm{H}, \mathrm{m}), 6.62(2 \mathrm{H}, \mathrm{br} \mathrm{s}), 4.88(2 \mathrm{H}, \mathrm{s}), 4.26(2 \mathrm{H}, \mathrm{t}, J=6.3 \mathrm{~Hz}), 4.06(2 \mathrm{H}$, $\mathrm{t}, J=6.6 \mathrm{~Hz}), 3.27(2 \mathrm{H}, \mathrm{t}, J=6.6 \mathrm{~Hz}), 1.54(2 \mathrm{H}, \mathrm{m}), 1.29(2 \mathrm{H}, \mathrm{m}), 0.87(3 \mathrm{H}$, t, $J=7.4 \mathrm{~Hz}$ ); MS (FAB) $m / z 418\left(\mathrm{MH}^{+}\right)$; HR-MS Calcd for $\mathrm{C}_{19} \mathrm{H}_{24} \mathrm{~N}_{5} \mathrm{O}_{4} \mathrm{~S}$ 418.1549, found 418.1552. Anal. Calcd for $\mathrm{C}_{19} \mathrm{H}_{23} \mathrm{~N}_{5} \mathrm{O}_{4} \mathrm{~S} \cdot 1 / 10 \mathrm{H}_{2} \mathrm{O}$ : C, $54.43 ; \mathrm{H}, 5.58 ; \mathrm{N}, 16.70$. Found: C, 54.43; H, 5.52; N, 16.40 .

9-Benzyl-8-butoxycarbonyloxy-2-(2-hydroxyethylthio)adenine (4) To a suspension of SM-295072 $(100 \mathrm{mg}, 0.315 \mathrm{mmol})$ and triethylamine (64 mg, $0.630 \mathrm{mmol})$ in $\mathrm{CHCl}_{3}(20 \mathrm{ml})$ was added dropwise butyl chloroformate $(65 \mathrm{mg}, 0.473 \mathrm{mmol})$ and the mixture was stirred at room temperature for $5 \mathrm{~h}$. The reaction mixture was poured into water and the organic layer was separated, dried over $\mathrm{Na}_{2} \mathrm{SO}_{4}$ and then evaporated in vacuo. The residue was purified by silica gel column chromatography $\left(1 \% \mathrm{MeOH}-\mathrm{CHCl}_{3}\right)$ to give $4(104 \mathrm{mg}, 79 \%)$ as a colorless solid. mp $146-148^{\circ} \mathrm{C}$; ${ }^{1} \mathrm{H}-\mathrm{NMR}$ (DMSO$\left.d_{6}\right) \delta 7.32(5 \mathrm{H}, \mathrm{m}), 7.11(2 \mathrm{H}, \mathrm{br} \mathrm{s}), 4.91(3 \mathrm{H}, \mathrm{m}), 4.33(2 \mathrm{H}, \mathrm{t}, J=6.3 \mathrm{~Hz})$, $3.60(2 \mathrm{H}, \mathrm{dt}, J=6.1,6.9 \mathrm{~Hz}), 3.14(2 \mathrm{H}, \mathrm{t}, J=6.9 \mathrm{~Hz}), 1.67(2 \mathrm{H}, \mathrm{m}), 1.44$ $(2 \mathrm{H}, \mathrm{m}), 0.91\left(3 \mathrm{H}, \mathrm{t}, J=7.3 \mathrm{~Hz}\right.$ ); MS (FAB) $m / z 418\left(\mathrm{MH}^{+}\right)$; HR-MS Calcd for $\mathrm{C}_{19} \mathrm{H}_{24} \mathrm{~N}_{5} \mathrm{O}_{4} \mathrm{~S}$ 418.1549, found 418.1547. Anal. Calcd for $\mathrm{C}_{19} \mathrm{H}_{23} \mathrm{~N}_{5} \mathrm{O}_{4} \mathrm{~S}$. 1/10 $\mathrm{H}_{2} \mathrm{O}: \mathrm{C}, 54.43 ; \mathrm{H}, 5.58 ; \mathrm{N}, 16.70$. Found: C, 54.60; H, 5.45; N, 16.46.

Compounds $5-\mathbf{8}$ were prepared using similar procedures as for 4 .

9-Benzyl-2-(2-hydroxyethylthio)-8-methoxycarbonyloxyadenine (5) Colorless solid (92\%), mp 186-188 ${ }^{\circ} \mathrm{C} ;{ }^{1} \mathrm{H}-\mathrm{NMR}$ (DMSO- $\left.d_{6}\right) \delta 7.31(5 \mathrm{H}$, m), $7.13(2 \mathrm{H}, \mathrm{br} \mathrm{s}), 4.89(3 \mathrm{H}, \mathrm{m}), 3.91(3 \mathrm{H}, \mathrm{s}), 3.56(2 \mathrm{H}, \mathrm{dt}, J=6.5,6.8 \mathrm{~Hz})$, $3.13(2 \mathrm{H}, \mathrm{t}, J=6.8 \mathrm{~Hz})$; MS (FAB) $\mathrm{m} / \mathrm{z} 376\left(\mathrm{MH}^{+}\right)$; HR-MS Calcd for $\mathrm{C}_{16} \mathrm{H}_{18} \mathrm{~N}_{5} \mathrm{O}_{4} \mathrm{~S} 376.1080$, found 376.1084 .

9-Benzyl-8-ethoxycarbonyloxy-2-(2-hydroxyethylthio)adenine (6) Colorless solid (88\%), mp 164-166 ${ }^{\circ} \mathrm{C} ;{ }^{1} \mathrm{H}-\mathrm{NMR}\left(\mathrm{DMSO}-d_{6}\right) \delta 7.31(5 \mathrm{H}$, $\mathrm{m}), 7.12(2 \mathrm{H}, \mathrm{brs}), 4.91(3 \mathrm{H}, \mathrm{m}), 4.38(2 \mathrm{H}, \mathrm{q}, J=7.0 \mathrm{~Hz}), 3.60(2 \mathrm{H}, \mathrm{dt}$, $J=6.2,6.6 \mathrm{~Hz}), 3.14(2 \mathrm{H}, \mathrm{t}, J=6.6 \mathrm{~Hz}), 1.32(3 \mathrm{H}, \mathrm{t}, J=7.0 \mathrm{~Hz})$; MS (FAB) $\mathrm{m} / \mathrm{z} 390\left(\mathrm{MH}^{+}\right)$; HR-MS Calcd for $\mathrm{C}_{17} \mathrm{H}_{20} \mathrm{~N}_{5} \mathrm{O}_{4} \mathrm{~S} 390.1236$, found 390.1237 . Anal. Calcd for $\mathrm{C}_{17} \mathrm{H}_{19} \mathrm{~N}_{5} \mathrm{O}_{4} \mathrm{~S}$ : C, 52.43; H, 4.92; N, 17.98. Found: C, 52.40; H, 4.76; N, 17.79 .

9-Benzyl-2-(2-hydroxyethylthio)-8-isopropoxycarbonyloxyadenine (7) Colorless solid (83\%), mp 160-161 ${ }^{\circ} \mathrm{C} ;{ }^{1} \mathrm{H}-\mathrm{NMR}$ (DMSO- $\left.d_{6}\right) \delta 7.31(5 \mathrm{H}$, m), $7.11(2 \mathrm{H}, \mathrm{brs}), 5.10(1 \mathrm{H}, \mathrm{m}), 4.91(3 \mathrm{H}, \mathrm{m}), 3.60(2 \mathrm{H}, \mathrm{dt}, J=6.1,6.6 \mathrm{~Hz})$, $3.14(2 \mathrm{H}, \mathrm{t}, J=6.6 \mathrm{~Hz}), 1.34(6 \mathrm{H}, \mathrm{d}, J=6.2 \mathrm{~Hz})$; MS (FAB) $\mathrm{m} / \mathrm{z} 404\left(\mathrm{MH}^{+}\right)$; 
HR-MS Calcd for $\mathrm{C}_{18} \mathrm{H}_{22} \mathrm{~N}_{5} \mathrm{O}_{4} \mathrm{~S}$ 404.1393, found 404.1391. Anal. Calcd for $\mathrm{C}_{18} \mathrm{H}_{21} \mathrm{~N}_{5} \mathrm{O}_{4} \mathrm{~S} \cdot 1 / 10 \mathrm{H}_{2} \mathrm{O}: \mathrm{C}, 53.35 ; \mathrm{H}, 5.27 ; \mathrm{N}, 17.28$. Found: $\mathrm{C}, 53.12 ; \mathrm{H}$, $5.27 ; \mathrm{N}, 17.39$.

9-Benzyl-2-(2-hydroxyethylthio)-8-isobutoxycarbonyloxyadenine (8) Colorless solid $(80 \%), \mathrm{mp} 144-145^{\circ} \mathrm{C} ;{ }^{1} \mathrm{H}-\mathrm{NMR}$ (DMSO- $\left.d_{6}\right) \delta 7.33(5 \mathrm{H}$, m), $7.12(2 \mathrm{H}, \mathrm{brs}), 4.90(3 \mathrm{H}, \mathrm{m}), 4.13(2 \mathrm{H}, \mathrm{d}, J=6.5 \mathrm{~Hz}), 3.60(2 \mathrm{H}, \mathrm{dt}$, $J=6.1,6.6 \mathrm{~Hz}), 3.14(2 \mathrm{H}, \mathrm{t}, J=6.6 \mathrm{~Hz}), 2.01(1 \mathrm{H}, \mathrm{m}), 0.97(6 \mathrm{H}, \mathrm{d}$, $J=6.8 \mathrm{~Hz}$ ); MS (FAB) $m / z 418\left(\mathrm{MH}^{+}\right)$; HR-MS Calcd for $\mathrm{C}_{19} \mathrm{H}_{24} \mathrm{~N}_{5} \mathrm{O}_{4} \mathrm{~S}$ 418.1549, found 418.1546. Anal. Calcd for $\mathrm{C}_{19} \mathrm{H}_{23} \mathrm{~N}_{5} \mathrm{O}_{4} \mathrm{~S}$ : C, 54.66; H, 5.55; N, 16.78. Found: C, 54.41; H, 5.56; N, 16.87 .

Parmacokinetic (PK) Evaluation in Rats Test compounds suspended in $0.5 \%$ CMC-Na solution were administered orally to male Sprague-Dawley rats (Charles River Japan Inc.) aged 8-10 weeks at a dose of $30 \mathrm{mg} / \mathrm{kg}$. At 1, 2, 4, 6, 8 and $24 \mathrm{~h}$ after administration, rats were anaesthetized with ether, and heparinized blood samples were collected via caudal vein. Then the plasma samples were prepared by centrifugation (12000 rpm for $10 \mathrm{~min})$, and stored at $-20^{\circ} \mathrm{C}$ until analyzed for PK studies.

The plasma samples were mixed with ethyl acetate, and the organic layer obtained was evaporated to dryness at $40{ }^{\circ} \mathrm{C}$, and then reconstituted in $50 \%$ methanol. The extract sample was injected into an HPLC system equipped with a Zorbax bonus RP column $(4.6 \times 150 \mathrm{~mm})$, and eluted with a linear gradient from 4 to $48 \%$ of acetonitrile in $0.1 \%$ aqueous trifluoroacetic acid at a flow rate of $1.0 \mathrm{ml} / \mathrm{min}$ and monitored with UV detection at $315 \mathrm{~nm}$. The drug concentration was calculated from the peak area using the calibration curve obtained from standard plasma samples (the lower quantification limit was $10 \mathrm{ng} / \mathrm{ml}$ ). PK parameters for the compounds were estimated by using a non-compartmental method. $C_{\max }$ and $T_{\max }$ were determined by inspection of individual subject concentration-time curves, and $A U C$ was determined by the linear trapezoidal rule.

PK Evaluation in Monkeys The test compounds were suspended in $0.5 \%$ CMC-Na solution, and administered orally to cynomolgus monkeys (Macaca fascicularis; $2.6-4.8 \mathrm{~kg}$ body weight) at doses of 10 and 100 $\mathrm{mg} / \mathrm{kg}$. At 1, 2, 4, 6, 8 and $24 \mathrm{~h}$ after administration, heparinized blood sam- ples were collected via femoral vein. Then plasma samples were prepared by centrifugation $\left(12000 \mathrm{rpm}\right.$ for $10 \mathrm{~min}$ ), and stored at $-20^{\circ} \mathrm{C}$ until analyzed for IFN and drug concentration. Drug concentration in monkey plasma was measured by the same methods as described in rat PK studies.

IFN Induction in Monkey IFN titer in plasma sample was quantitated by measuring its antiviral activity in a bioassay using mouse L929 cell monolayers challenged with vesicular stomatitis virus. Results are expressed as IFN IU/ml in terms of the international IFN standard obtained from the National Institute of Health, Bethesda, MD.

\section{References}

1) St. Georgiev V., Trend Pharmacol. Sci., 8, 446- 451 (1988).

2) Sen G. C., Lengyel P., J. Biol. Chem., 267, 5017-5020 (1992).

3) Dianzani F., J. Interferon Res., 12, 109-118 (1992).

4) Spiegel R. J., Urology, 34, 75-79 (1989).

5) Pfeffer L. M., Dinarello C. A., Herbermann R. B., Williams B. R. G., Borden E. C., Bordens R., Walter M. R., Nagabhushan T. L., Trotta P. P., Pestka S., Cancer Res., 58, 2489-2499 (1998).

6) Ashmed A., Keefe E. B., J. Gastroenterol. Hepatol., 14, S12-S18 (1999).

7) Rönnblom L. E., Janson E. T., Perers A., Öberg K. E., Alm G. V., Clin. Exp. Immunol., 89, 330-335 (1992).

8) Steis R. G., Smith J. W., Urba W. J., Clark J. W., Itri L. M., Evans L. M., Schoenberger C., Longo D. L., N. Engl. J. Med., 318, 1409-1423 (1988).

9) Hirota K., Kazaoka K., Niimoto I., Kumihara H., Sajiki H., Isobe Y., Takaku H., Tobe M., Ogita H., Ogino T., Ichii S., Kurimoto A., Kawakami H., J. Med. Chem., 45, 5419-5422 (2002).

10) Based on MEDI41 presented at the 224th ACS National Meeting, Boston, MA, U.S.A., on 18 August 2002.

11) Wagner T. L., Horton V. L., Carlson G. L., Myhre P. E., Gibson S. J., Imbertson L. M., Tomai M. A., Cytokine, 9, 837—845 (1997). 